\title{
Heterosis in Relation to Combining Ability Variances in Eggplant (Solanum melongena L.)
}

\author{
Mahmoud, I. M. \\ Plant Production Department (Vegetable). Fac. Environ. Agric. Sci., El-Arish, Suez Canal Univ., Egypt \\ Received: $2 / 6 / 2014$
}

\begin{abstract}
This study was carried out at the Experimental Farm, Fac. of Environ. Agric. Sci., El Arish, Suez Canal Univ., Egypt, during three successive summer seasons (2009 to 2011). Seven elongated eggplant fruit lines were used in $7 \times 7$ half- diallel cross mating design to produce $21 F_{1}$ hybrids. In the two successive summer seasons of 2010 and 2011 , all 28 genotypes were evaluated in a field experiment with check hybrid "Snow $\mathrm{F}_{1}$ ". A randomized complete block design with three replicates was used in the two seasons of 2010 and 2011 to estimate heterosis relative to mid parents, better parent and check hybrid, also dominance type and its relation to combining ability variances were determine for some plant and fruit characters. The obtained results showed high significant differences among the parental lines and their $21 \mathrm{~F}_{1}$ hybrids for all studied traits. Heterosis over mid-parents, better parent and check hybrid were recorded in 14 , 8 and 4 ones for total fruit yield/plant, respectively. However, heterosis over mid-parents and check hybrid were reflected by 5 and 4 crosses for number of branches, 5 and 12 ones for number of fruits/cluster, 10 and 15 ones for percent of fruit clusters/plant and 8 and 11 ones for total fruit number/plant, respectively. However, no heterosis was detected for average fruit weight, fruit length and diameter. Determination of dominance type and GCA and SCA variances showed that additive gene action play the main role in the inheritance of all studied traits, except total yield/plant trait. The non-additive gene action was predominance and more important in the inheritance of total yield/plant.
\end{abstract}

Keywords: Heterosis, Combining Ability Variances, Eggplant.

\section{INTRODUCTION}

Eggplant (Solanum melongena L.) is one from the important solanaceous vegetable crops cultivated in tropical and subtropical regions of the world and grown all around the year in Egypt. It is cultivated for its unripe fruits which are used in various ways as fresh, pickled, fried and cooked food. In Egypt, some consumers prefer long fruit type, with white or purplish white color, so it is necessary to develop varieties and hybrids with high yield, quality and having desirable color.

Exploitation of heterosis in eggplant has been recognized as a practical tool in providing the breeders with means of increasing yield and other economic traits. Heterosis studies give idea about different types of gene effects which can be utilized further for improvement (Jain and Sastry, 2012). The success of breeding procedure is determined by the useful gene combinations organized in the form of good combining lines and isolation of valuable germplasm.

Heterosis in eggplant over mid-parents, better parent and commercial hybrid were studied and observed by many researchers among them, Mandal and Dana (1993) for total yield, Mankar et al. (1995) for number of branches, fruit length, diameter, number of fruits and total yield/plant, Ingale and Patil (1996) for fruit length, diameter, average fruit weight and total yield and Prasath et al. (1998) for total yield, number of branches, fruit length, average fruit weight and number of fruits/plant. Shafeeq et al. (2007) found heterosis over mid-parents, better parent and check hybrid for number of fruits/cluster and total yield/plant. Sao and Mehta (2010) showed significant heterosis over better parent for number of fruits/cluster $(98.73 \%)$, average fruit weight $(83.27 \%)$ and number of branches
(41.69\%). Heterosis over mid-parents, better parent and commercial hybrid were detected in 7, 4 and 1 cross from 12 ones for total yield (Ramireddy et al., 2011) they also showed heterosis for number of fruits/cluster and average fruit weight. Singh et al. (2012) found significant heterosis over better parent for fruit length, diameter, number of fruits and total yield/plant. In other studies, significant positive heterosis was observed for number of branches, number of clusters/plant, number of fruits/clusters, while negative heterosis was observed for fruit diameter (Saraswathi, 2003).

Additive and non- additive gene action involved in the inheritance of important traits is required in order to frame an efficient breeding plan leading to rapid improvement. In the inheritance of eggplant traits many studies revealed that, additive gene action played the important role, among them Ingale and Patil (1997) for fruit length and diameter, Ahmed et al. (2006) for fruit diameter and average fruit weight, Rai et al. (1998) for average fruit weight, total yield, fruit length and number of fruits, Chezhian et al. (2000) for fruit number, average fruit weight and total yield, Das and Barua (2001) for fruit length, diameter, average fruit weight and number of branches, Singh et al. (2002) for number of branches, fruit diameter, average fruit weight and number of fruits/plant and Patil et al. (2006) for number of branches/plant, total yield and total fruit number. On the other hand, the preponderances of non-additive gene actions were observed by other researchers; viz., Ingale and Patil (1997) for average fruit weight and total yield/plant; Aswani and Khandelwal (2005) for number of clusters/plant, fruit length, diameter, number of fruits, average fruit weight and total yield, and Bendale et al. (2005) and Suneetha and Kathiria (2006) for number of branches and total yield/plant. On the other hand, some investigators found that both additive and non- additive gene effects were approximately similar in the 
inheritance of these traits, among them, Kavita et al. (2005) for total fruit weight and number of fruit/plant and Ahmed et al. (2006) for fruit length, number of fruits and total fruit yield/plant. The objectives of the present study were to determine average degree of heterosis, dominance type and general and specific combining ability variances to gain information about mode of gene actions in order to identify superior hybrids of excellent qualities coupled with high yields.

\section{MATERIALS AND METHODS}

The present study was carried out at the Experimental Farm, Faculty of Environmental Agricultural Sciences, El Arish, Suez Canal University, Egypt, during three successive summer seasons from 2009 to 2011 . The genetic materials used in this study were seven elongated eggplant fruit lines; viz., LW 6-1, LW 14-1, CLW 1-1, CLW 4-2, LPW 2-1-6, LPW 12-3 and LB 78-4-1. Seeds of these materials were obtained from Veg. Res. Dep., Hort. Res. Inst., Agric. Res. Center, Giza, Egypt (Kansouh and Hussien, 2009). In the summer season of 2009, the parental lines were used in $7 \times 7$ half- diallel cross mating design, to produce $21 \mathrm{~F}_{1}$ hybrids. In the two successive summer seasons of 2010 and 2011, all genotypes (seven parents and their $21 \mathrm{~F}_{1}$ hybrids) were evaluated in a field experiment with the commercial $F_{1}$ hybrid "Snow" as a check hybrid. In the three seasons, the seedlings were transplanted in the field in the first week of March. A randomized complete block design with three replicates was used in the two seasons of 2010 and 2011, each replicate contained 29 plots, the plot area was $24 \mathrm{~m}^{2}(24 \mathrm{~m}$ long and $1.0 \mathrm{~m}$ width). Drip irrigation system was used, dripper lines were spaced $1 \mathrm{~m}$ between each other, plants spaced 50 $\mathrm{cm}$ in the same row. Other normal agricultural practices for eggplant production were done as recommended in the open field in North Sinai region.

\section{The studied characters:}

After four months from transplanting, 10 plants were randomly chosen from each plot to calculate number of primary branches/plant. Number of fruits /cluster and percent of fruit clusters/plant were determined during one month at the middle of growth season. Total fruit weight $(\mathrm{kg})$ and number /plant were calculated from all harvested fruits. Average fruit weight $(\mathrm{g})$ was calculated by dividing total weight of all harvested fruits over total number of fruits. Fifteen fruits from each plot were taken randomly from the fourth harvest to determine fruit length $(\mathrm{cm})$ and diameter $(\mathrm{cm})$, while fruit color was determined visually at marketable and ripening stages.

Data were recorded during the two seasons of 2010 and 2011, then the combined data over the two seasons were calculated and statistically analyzed as outlined by Cochran and Cox (1957), in order to test the significance of the differences among the various means according to the least significant differences (L.S.D.) (Snedecor and Cochran, 1990). Average degree of heterosis $(\mathrm{ADH} \%)$ was estimated as a percent increase or decrease of $\mathrm{F}_{1}$ performance from the mid parents $(\mathrm{MPH} \%)$, better parent $(\mathrm{PBH} \%)$ and check hybrid
$(\mathrm{CH} \%)$. Dominance types (no, partial, complete and over dominance) were obtained according to the dominance line which depended on the results of $\mathrm{MPH} \%$ and $\mathrm{BPH} \%$ values (Kansouh, 2014). Heterosis over the better parent (BPH\%) was only calculated for the crosses that showed significant positive $\mathrm{MPH} \%$ values (the genotypes which showed zero percentage of fruit clusters/plant were considered equal one to calculate average degree of heterosis). General and specific combining ability analysis of variances $\left(\sigma^{2} \mathrm{GCA}\right.$ and $\sigma^{2} \mathrm{SCA}$ ), were done as reported by Griffing (1956), method II - model I.

\section{RESULTS AND DISCUSSION}

\section{Mean performance of parents and their $F_{1}$ hybrids:}

Data presented in Table 1 show high significant differences among the parental lines and $21 \mathrm{~F}_{1}$ hybridsfor all studied traits. For number of primary branches/plant, the two lines CLW 4-2 and LPW 2-1-6 had the highest number (9.0 and 8.03, respectively), while the lowest parents were LW 6-1 and LB 78-4-1 (5.97 and 6.03, respectively). With regard to crosses, four crosses (LW 6-1xCLW 4-2, LW 14-1xCLW 4-2, CLW 1-1xCLW 42 and CLW 4-2xLPW 2-1-6) had the highest number of primary branches/plant $(10.23,10.03,9.43$ and 9.43, respectively) and significantly exceeded that of the check hybrid (Snow). In general, the overall mean of $F_{1}$ hybrids exceeded that of parental lines by heterosis value of $10.47 \%$.

For number of fruits/cluster and percent of fruit clusters/plant (Table 1), only the three lines CLW1-1, CLW4-2 and LB78-4-1 produced fruit number/cluster (4.67, 3.33 and 1.67, respectively) and percent of fruit clusters/plant (75.67, 60.82 and $22.75 \%$, respectively). For crosses, 15 ones showed percent of fruit clusters/plant, values ranged from 12.53 in the cross LPW12-3xLB78-4-1 to 71.38 in the crossCLW1$1 \times C L W 4-2$ and significantly exceeded that of the check hybrid. The same trend was observed also for number of fruits/cluster. In both traits, the cross CLW1-1xCLW4-2 showed the highest values for the two traits. However, this cross involved the high two parents for these two traits. The overall mean of the crosses significantly exceeded that of their parents by heterosis valuesof $12.82 \%$ and $45.03 \%$ for number of fruits/cluster and percent of fruit cluster/plant, respectively (Table 1).

Concerning total yield/plant, data in Table 1 show high differences among parents, where the values ranged from 2.785 to $3.872 \mathrm{~kg} /$ plant, the highest yield was produced by the line CLW4-2 $(3.872 \mathrm{~kg} / \mathrm{plant})$ followed by LPW2-1-6 (3.665kg/plant), while the lowest one was LW6-1(2.785kg/plant). The overall mean of $F_{1}$ crosses $(3.612 \mathrm{~kg} / \mathrm{plant})$ exceeded that of their parental line (3.291) by $9.69 \%$. The hybrids showed values ranged from 2.816 to $4.279 \mathrm{~kg} / \mathrm{plant}$. The two crosses LW6-1xCLW4-2 and LW14-1xCLW4-2 produced the highest total yield (4.279 and 4.234 $\mathrm{kg}$ /plant, respectively)and significantly exceeded the check hybrid "Snow $\mathrm{F}_{1}$ " (3.887 kg/plant) by $10.08 \%$ and $8.93 \%$, respectively, indicating that these promise 
crosses could be introduced or replaced "Snow $\mathrm{F}_{1}$ " in the commercial cultivation.

For total fruit number/plant, data presented in Table1 show that parental lines CLW1-1 and CLW4-2 recorded the highest number (128.36 and 124.86 fruits/plant, respectively), while the lowest number of fruits (49.93) was obtained by the line LW6-1. Among the studied crosses, CLW1-1xCLW4-2 and CLW1-
1xLB78-4-1 produced the highest number of fruits (127.67 and 115.17, respectively), while the lowest number (53.72) was observed in the cross LW61xLPW12-3, also eleven crosses significantly exceeded that of the check hybrid "Snow $\mathrm{F}_{1}$ ". Generally, the overall mean value of the $F_{1}$ crosses (85.26) exceeded that of parental lines (79.84) by $6.78 \%$ and check hybrid (64.16) by $32.89 \%$.

Table (1): Mean performances of the evaluated eggplant F1 hybrids and their parents for some plant characteristics

\begin{tabular}{|c|c|c|c|c|c|}
\hline Intries & $\begin{array}{l}\text { No. of primary } \\
\text { branches/plant }\end{array}$ & $\begin{array}{l}\text { No .of fruits } \\
\text { /cluster }\end{array}$ & $\begin{array}{l}\text { Percent of fruit } \\
\text { clusters/plant }\end{array}$ & $\begin{array}{l}\text { Total yield } \\
\text { /plant (kg) }\end{array}$ & $\begin{array}{c}\text { total fruit } \\
\text { number } \\
\text { /plant }\end{array}$ \\
\hline LW.6-1 & 5.97 & 1.000 & 0.00 & 2.785 & 49.93 \\
\hline LW.14-1 & 6.50 & 1.000 & 0.00 & 2.941 & 57.02 \\
\hline CLW.1-1 & 7.03 & 4.667 & 75.67 & 3.21 & 128.36 \\
\hline CLW.4-2 & 9.00 & 3.333 & 60.82 & 3.872 & 124.86 \\
\hline LPW.2-1-6 & 8.03 & 1.000 & 0.00 & 3.665 & 61.98 \\
\hline LPW.12-3 & 6.96 & 1.000 & 0.00 & 3.028 & 59.97 \\
\hline LB.78-4-1 & 6.03 & 1.667 & 22.75 & 3.541 & 76.78 \\
\hline Mean & 7.08 & 1.950 & 22.75 & 3.291 & 79.84 \\
\hline \multicolumn{6}{|l|}{ Crosses } \\
\hline LW.6-1 x LW14-1 & 6.60 & 1.000 & 0.00 & 2.816 & 57.24 \\
\hline LW.6-1 x CLW1-1 & 7.83 & 4.000 & 66.08 & 3.876 & 100.78 \\
\hline LW6-1 x CLW4-2 & 10.23 & 3.667 & 57.1 & 4.279 & 95.21 \\
\hline LW.6-1 x LPW2-1-6 & 7.50 & 1.000 & 0.00 & 3.538 & 86.52 \\
\hline LW.6-1 x LPW12-3 & 6.83 & 1.000 & 0.00 & 2.94 & 53.72 \\
\hline LW.6-1 x LB.78-4-1 & 6.23 & 1.333 & 15.55 & 3.308 & 64.66 \\
\hline LW.14-1 x CLW.1-1 & 7.00 & 3.333 & 62.67 & 3.938 & 105.88 \\
\hline LW.14-1 x CLW.4-2 & 10.03 & 3.333 & 58.43 & 4.234 & 98.13 \\
\hline LW.14-1 x LPW.2-1-6 & 7.40 & 1.000 & 0.00 & 3.428 & 62.84 \\
\hline LW.14-1 x LPW.12-3 & 6.90 & 1.000 & 0.00 & 2.925 & 59.06 \\
\hline LW.14-1 x LB.78-4-1 & 6.57 & 1.667 & 14.78 & 3.273 & 67.23 \\
\hline CLW.1-1 x CLW.4-2 & 9.43 & 4.333 & 71.38 & 4.012 & 127.67 \\
\hline CLW.1-1 x LPW.2-1-6 & 8.83 & 3.000 & 65.33 & 3.861 & 110.31 \\
\hline CLW.1-1 x LPW.12-3 & 7.50 & 2.667 & 55.17 & 3.705 & 93.89 \\
\hline CLW.1-1 x LB.78-4-1 & 6.50 & 3.333 & 62.38 & 3.561 & 115.17 \\
\hline CLW.4-2 x LPW.2-1-6 & 9.43 & 2.667 & 47.45 & 4.059 & 105.83 \\
\hline CLW.4-2 x LPW.12-3 & 8.33 & 2.333 & 38.62 & 3.77 & 103.58 \\
\hline CLW.4-2 x LB.78-4-1 & 8.30 & 2.333 & 51.80 & 3.939 & 102.50 \\
\hline LPW.2-1-6 x LPW.12-3 & 8.43 & 1.000 & 0.00 & 3.406 & 62.66 \\
\hline LPW.2-1-6 x LP.78-4-1 & 7.30 & 1.333 & 13.43 & 3.596 & 68.87 \\
\hline LPW.12-3 x LB.78-4-1 & 6.83 & 1.333 & 12.53 & 3.366 & 66.65 \\
\hline Mean & 7.82 & 2.210 & 32.98 & 3.612 & 85.26 \\
\hline Average of heterosis & 10.47 & 12.820 & 45.03 & 9.69 & 6.78 \\
\hline Snow F1 & 8.10 & 1.000 & 0.00 & 3.887 & 64.16 \\
\hline L.S.D.5\% & 1.25 & 0.57 & 5.60 & 0.332 & 8.43 \\
\hline L.S.D.1\% & 1.79 & 0.82 & 8.01 & 0.475 & 12.07 \\
\hline
\end{tabular}

Regarding average fruit weight, data presented in Table 2 show that the parental lines showed values ranged from 25.06 to $59.61 \mathrm{~g}$ with a mean value of 45.80g. The line LPW 2-1-6 recorded the heaviest fruits (59.61g) followed by the line LW6-1 with a value of $55.94 \mathrm{~g}$. On the other hand, the lightest average fruit weight $(25.06$ and $31.07 \mathrm{~g})$ were recorded by the two lines CLW1-1and CLW4-2, respectively. The resulted hybrids produced fruits with average weight ranged from $30.97 \mathrm{~g}$ (in the cross CLW1-1xLB78-4-1) to $55.34 \mathrm{~g}$ (in the cross LW6-1xLPW12-3) with a mean value of $44.47 \mathrm{~g}$. Concerning fruit length and diameter (Table 2), the line LW14-1produced the longest fruits $(25.47 \mathrm{~cm})$, while the line LW6-1 showed the highest fruit diameter value $(6.63 \mathrm{~cm})$. On the contrary, the two lines CLW1-1 and CLW4-2 produced the shortest and thinnest fruits. They showed fruits with length of 14.13 and $16.47 \mathrm{~cm}$, respectively, with diameter of 3.03 and $3.69 \mathrm{~cm}$, respectively. The resulted hybrids produced fruits ranged from 15.13 to $25.03 \mathrm{~cm}$ in length, and from 3.50 to $6.20 \mathrm{~cm}$ in diameter. The cross LW14$1 \times L B 78-4-1$ produced the longest fruits $(25.03 \mathrm{~cm})$, 
while the cross LW6-1xLPW2-1-6 showed the highest fruit diameter value $(6.20 \mathrm{~cm})$. On the other hand, the cross CLW1-1xCLW4-2 produced the shortest and thinnest fruits (15.13 and $3.5 \mathrm{~cm}$, respectively). Generally, the cross CLW1-1xCLW4-2 and their parents recorded the lowest values for average fruit weight, fruit length and diameter. These low values may be attributed to fruit bearing habit, since they produced cluster fruit type involved 4-5 fruits per cluster, as mentioned before.

Data obtained (Table 2) showed great variations in fruit color among the studied lines and their hybrids, at both marketable and ripening stages.

Table (2): Mean performances of the evaluated eggplant F1 hybrids and their parents for some fruit characteristics

\begin{tabular}{|c|c|c|c|c|c|}
\hline $\begin{array}{ll}\text { Intries } & \text { Characters }\end{array}$ & $\begin{array}{c}\text { Average fruit } \\
\text { weight (g.) }\end{array}$ & $\begin{array}{l}\text { Fruit length } \\
\text { (cm) }\end{array}$ & $\begin{array}{c}\text { Fruit } \\
\text { diameter(cm) }\end{array}$ & $\begin{array}{c}\text { Fruit color at } \\
\text { marketable stage }\end{array}$ & $\begin{array}{l}\text { Fruit color at } \\
\text { ripening stage }\end{array}$ \\
\hline LW.6-1 & 55.94 & 22.07 & 6.63 & White & Yellow \\
\hline LW.14-1 & 51.82 & 25.47 & 4.63 & White & Yellow \\
\hline CLW.1-1 & 25.06 & 14.13 & 3.03 & White & Yellow \\
\hline CLW.4-2 & 31.07 & 16.47 & 3.69 & White & Yellow \\
\hline LPW.2-1-6 & 59.61 & 23.43 & 5.56 & Purplish-white & Dark-yellow \\
\hline LPW.12-3 & 50.83 & 19.50 & 4.53 & Light purple & Dark-yellow \\
\hline LB. $78-4-1$ & 46.26 & 24.97 & 5.03 & Black & Brown \\
\hline Mean & 45.8 & 20.86 & 4.73 & & \\
\hline \multicolumn{6}{|l|}{ Crosses } \\
\hline LW.6-1 x LW14-1 & 49.40 & 24.03 & 6.03 & White & Yellow \\
\hline LW.6-1 x CLW1-1 & 38.53 & 20.07 & 5.67 & White & Yellow \\
\hline LW6-1 x CLW4-2 & 45.08 & 20.53 & 6.03 & White & Yellow \\
\hline LW.6-1 x LPW2-1-6 & 51.65 & 23.03 & 6.20 & Purplish-white & Dark-yellow \\
\hline LW.6-1 x LPW12-3 & 55.34 & 21.10 & 5.77 & Purplish-white & Dark-yellow \\
\hline LW.6-1 x LB.78-4-1 & 51.62 & 24.07 & 6.13 & Brown & Light-brown \\
\hline LW.14-1 x CLW.1-1 & 37.24 & 22.50 & 4.07 & White & Yellow \\
\hline LW.14-1 x CLW.4-2 & 43.18 & 23.10 & 5.53 & White & Yellow \\
\hline LW.14-1 x LPW.2-1-6 & 54.65 & 24.03 & 5.33 & Purplish-white & Dark-yellow \\
\hline LW.14-1 x LPW.12-3 & 49.72 & 23.53 & 4.63 & Purplish-white & Dark-yellow \\
\hline LW.14-1 x LB.78-4-1 & 49.38 & 25.03 & 5.03 & Brown & Light-brown \\
\hline CLW.1-1 x CLW.4-2 & 31.43 & 15.13 & 3.50 & White & Yellow \\
\hline CLW.1-1 x LPW.2-1-6 & 35.07 & 21.03 & 4.90 & Purplish-white & Dark-yellow \\
\hline CLW.1-1 x LPW.12-3 & 39.50 & 17.53 & 4.10 & Purplish-white & Dark-yellow \\
\hline CLW.1-1 x LB.78-4-1 & 30.97 & 22.53 & 4.50 & Brown & Light-brown \\
\hline CLW.4-2 x LPW.2-1-6 & 38.47 & 21.53 & 5.07 & Purplish-white & Dark-yellow \\
\hline CLW.4-2 x LPW.12-3 & 36.43 & 18.60 & 4.33 & Purplish-white & Dark-yellow \\
\hline CLW.4-2 x LB.78-4-1 & 38.57 & 23.03 & 4.73 & Brown & Light-brown \\
\hline LPW.2-1-6 x LPW.12-3 & 54.50 & 22.07 & 5.20 & Purple & Light-brown \\
\hline LPW.2-1-6 x LP.78-4-1 & 52.38 & 24.07 & 5.53 & Brown & Light-brown \\
\hline LPW.12-3 x LB.78-4-1 & 50.67 & 23.53 & 5.03 & Brown & Light-brown \\
\hline Mean & 44.47 & 21.91 & 5.07 & & \\
\hline Average of heterosis & -2.90 & 5.03 & 6.97 & & \\
\hline Snow F1 & 60.93 & 21.03 & 7.03 & White & Yellow \\
\hline L.S.D.5\% & 4.73 & 3.91 & 1.44 & & \\
\hline L.S.D.1\% & 6.76 & 5.59 & 2.06 & & \\
\hline
\end{tabular}

The lines and their hybrids produced fruits with color degreed from white to dark. However, the fruit color at marketable stage vs. ripening stage as follow: white vs. yellow, purplish white and light purple vs. dark yellow, purple and brown vs. light brown and black vs. brown. These results are in agreement with those of Rai et al. (1998), Das and Barua (2001), Kaur et al. (2001), Kumar et al. (2012) and Praneetha et al. (2013) who found significant differences among evaluated lines and hybrids for most studied traits. Also, the results confirmed those of Valavigna (2007), Rotino et al. (2007) and Kansouh and Hussein (2009) regarding cluster fruit type.
Average degree of heterosis, dominance type and combining ability variances:

Data presented in Table 3 show that 16 crosses from 21 ones exhibited insignificant values relative to mid parent values, indicating no dominance for number of primary branches/plant in these crosses. However, 5 crosses showed dominance toward the high parent, since they showed significant positive mid parents heterosis (MPH\%) values ranging from $17.26 \%$ (in the cross CLW1-1xLPW2-1-6) to $36.67 \%$ (in the cross LW6$1 \times C L W 4-2)$. Heterosis over the better parent (BPH\%) for these 5 crosses showed complete dominance to the high parent, since they exhibited insignificant values. 
Compared with the check hybrid, four crosses showed significant or highly significant positive heterosis values. The cross LW6-1xLPW2-1-6 reflected the highest value (26.3\%). It is clear from the previous data (Table 3), the distribution of the crosses were: 16 ones showed no dominance, suggesting additive variance effects, and 5 ones showed complete dominance, suggesting non additive effects. Therefore, the inheritance of primary branches is mainly controlled by additive gene effects. This suggestion was confirmed by calculating the mean square values due to general and specific combining ability variance (Table 3), which were highly significant and insignificant, respectively, indicating the importance of additive gene action in the inheritance of this trait. In addition, the estimated $\sigma^{2} \mathrm{GCA} / \sigma^{2} \mathrm{SCA}$ ratio was 2.5 , indicating that additive gene action plays the main role in the inheritance of primary branches/plant. Similar results were obtained byMankar et al. (1995), Prasath et al. (1998) and Saraswathi (2003) who showed heterosis for this trait. Also, Das and Barua (2001), Singh et al. (2002) and Patil et al. (2006) found that additive gene action played the main role in the inheritance of this trait.

Table (3): Average degree of heterosis (ADH\%) based on mid-parents (MP), better parent (BP), commercial hybrid $(\mathrm{CH})$, dominance type and combining ability variances for number of primary branches/plant in eggplant.

\begin{tabular}{|c|c|c|c|c|}
\hline \multirow{2}{*}{ Crosses } & \multicolumn{3}{|c|}{ ADH\% } & \multirow{2}{*}{ Dominance type } \\
\hline & MP & BP & $\mathbf{C H}$ & \\
\hline LW.6-1 x LW14-1 & 5.85 & & $-18.52 *$ & No-dominance \\
\hline LW.6-1 x CLW1-1 & $20.46^{*}$ & 11.38 & -3.33 & Complete dominance \\
\hline LW6-1 x CLW4-2 & $36.67 * *$ & 13.67 & $26.3 * *$ & Complete dominance \\
\hline LW.6-1 x LPW2-1-6 & 7.14 & & -7.41 & No-dominance \\
\hline LW.6-1 x LPW12-3 & 5.64 & & $-15.68 *$ & No-dominance \\
\hline LW.6-1 x LB.78-4-1 & 3.83 & & $-23.08 * *$ & No-dominance \\
\hline LW.14-1 x CLW.1-1 & 3.47 & & -13.58 & No-dominance \\
\hline LW.14-1 x CLW.4-2 & $29.42 * *$ & 11.44 & $23.83 * *$ & Complete dominance \\
\hline LW.14-1 x LPW.2-1-6 & 1.86 & & -8.64 & No-dominance \\
\hline LW.14-1 x LPW.12-3 & 2.53 & & -14.81 & No-dominance \\
\hline LW.14-1 x LB.78-4-1 & 4.87 & & $-18.89 *$ & No-dominance \\
\hline CLW.1-1 x CLW.4-2 & $17.65^{*}$ & 4.78 & $16.42 *$ & Complete dominance \\
\hline CLW.1-1 x LPW.2-1-6 & $17.26^{*}$ & 9.96 & 9.01 & Complete dominance \\
\hline CLW.1-1 x LPW.12-3 & 7.22 & & -7.41 & No-dominance \\
\hline CLW.1-1 x LB.78-4-1 & -0.46 & & $-19.75 *$ & No-dominance \\
\hline CLW.4-2 x LPW.2-1-6 & 10.75 & & $16.42 *$ & No-dominance \\
\hline CLW.4-2 x LPW.12-3 & 4.38 & & 2.84 & No-dominance \\
\hline CLW.4-2 x LB.78-4-1 & 10.45 & & 2.47 & No-dominance \\
\hline LPW.2-1-6 x LPW.12-3 & 12.47 & & 4.07 & No-dominance \\
\hline LPW.2-1-6 x LB.78-4-1 & 3.84 & & -9.88 & No-dominance \\
\hline LPW.12-3 x LB.78-4-1 & 5.16 & & $-15.68 *$ & No-dominance \\
\hline \multicolumn{5}{|c|}{ Mean sum of square and variance (MS \& $\left.\sigma^{2}\right)$} \\
\hline & & GCA & SCA & \\
\hline & Ms & $4.88 * *$ & 0.481 & \\
\hline & $\sigma^{2}$ & 0.511 & 0.201 & \\
\hline & $\mathrm{A} / \sigma^{2} \mathrm{SCA}$ & & & \\
\hline
\end{tabular}

Concerning number of fruits/cluster, data in Table 4 show that, out of 21 crosses, only 5 ones exhibited significant positive values of heterosis over mid parents, suggesting dominance towards the high parent. The remaining 16 ones showed insignificant values, indicating no dominance for this trait. Heterosis over the better parent for these 5 crosses showed different degrees of dominance, since 3 crosses showed significant negative $\mathrm{BPH} \%$ values suggesting partial dominance and two ones showed complete dominance, since they reflected insignificant $\mathrm{BPH} \%$ values. Relative to the check hybrid, heterosis was detected in 12 crosses, where they showed significant positive values ranging from $67 \%$ (LW14-1xLB78-4-1) to $333 \%$ (CLW1-1xCLW4-2). From the previous data for number of fruits/cluster, the additive variance was predominance and play the main role in the inheritance of this trait, since no dominance was found in most crosses (16 ones), while 2 ones showed complete dominance suggesting non additive effects, as well as 3 ones reflected both additive and non-additive, since they showed partial dominance. Analysis of variance for combining ability revealed highly significant mean square values due to GCA and SCA, indicating that both additive and non- additive genetic variance were important in the inheritance of this trait. However, the $\sigma^{2} \mathrm{GCA} / \sigma^{2} \mathrm{SCA}$ ratio was more than unity (7.5), indicating that additive gene effects played a greater role in the inheritance of this trait. Heterosis were observed for number of fruits/cluster by Saraswathi (2003), Shafeeq et al. (2007) and Ramiereddy et al. (2011). For percent of fruit clusters/plant, data in Table 
5 illustrate that, 11 crosses showed no dominance, since they recorded insignificant mid parent's heterosis values. Partial dominance for high percent of clusters was found in 8 crosses, since they had significant positive heterosis values over mid parents and significant negative values of heterosis over the better parent. However, two crosses showed complete dominance to the high percent, since they reflected insignificant heterosis values over the better parent. Out of 21 crosses, 15 ones revealed highly significant positive values of heterosis over the check hybrid.

The highest value $(7038 \%)$ was reflected by the cross CLW1-1xCLW4-2, followed by value of $6508 \%$ in the cross LW6-1xCLW1-1. According to the previous result, the additive variance was predominance and played the main role in the inheritance of this trait, since most crosses ( $11 \mathrm{~F}_{1}$ 's) showed no dominance, and eight crosses reflected additive and non-additive (partial dominance) effects, while only two crosses exhibited complete dominance that expressed non additive variance. The results are confirmed by analysis of variance for combining ability which revealed highly significant mean square values due to GCA and SCA, indicating that both additive and non-additive gene actions played a significant role for the expression of this trait. Meanwhile, $\sigma^{2} \mathrm{GCA} / \sigma^{2} \mathrm{SCA}$ ratio was 3.6, indicating that additive gene action was prevalence and played the main role in the inheritance of percent of fruit clusters/plant. Significant positive heterosis for percent of fruit cluster/plant was observed by Saraswathi (2003).

As for total yield /plant, data in Table 6 show that from 21 crosses, 14 ones exhibited significant positive heterosis values over mid-parents, indicating dominance toward the high total yield, while the remaining seven ones showed insignificant MPH\% values, indicating nodominance for this trait in these crosses. Estimate of heterosis over the better parent for the 14 crosses, eight ones exhibited over dominance, three ones showed partial dominance and other three ones exhibited complete dominance, since they showed significant positive, significant negative and insignificant values of heterosis over the better parent, respectively. Only four crosses (LW6-1xCLW4-2, LW14-1xCLW4-2, CLW42xLPW2-1-6 and LW1-1xCLW4-2) from 21 ones showed significant and highly significant positive values of heterosis over the check hybrid $(10.08,8.93$, 4.43 and $3.24 \%$, respectively). It is obvious from Table 6 , that the studied crosses are distributed as follow, seven ones showed no-dominance, suggesting additive variance effects, 11 ones showed complete and over dominance, suggesting non-additive effects, while the remaining three ones showed partial dominance, indicating both of additive and non-additive effects. Therefore, the inheritance of total yield/plant under this study was controlled by non-additive gene effects. This suggestion was confirmed by the analysis of variance for combining ability, where both GCA and SCA mean squares were highly significant, indicating that both additive and non- additive genetic variances were involved in the inheritance of total yield/plant. The estimated ratio of $\sigma^{2} \mathrm{GCA} / \sigma^{2} \mathrm{SCAwas} 0.6$, which confirms the above results that non-additive was more important in the inheritance of this trait. Similar results were obtained by many investigators regarding average degree of heterosis for total yield, among them, Das and Barua (2001), Kauret al. (2001), Shafeeq et al. (2007) and Ramireddy et al. (2011). Also, Ingale and Patil (1997), Aswani and Khandelwal (2005), Bendale et al. (2005) and Suneetha and Kathiria (2006) reported that preponderance of non-additive gene actions in the inheritance of total yield.

Regarding total fruit number/plant, the obtained data (Table 7) showed that, 13 crosses had insignificant heterosis values relative to mid- parents, indicating nodominance for the trait. The remaining 8 crosses reflected heterosis over mid-parents, since they recorded highly significant positive values ranging from $8.82 \%$ (in the cross LW6-1xCLW4-2) to $22.46 \%$ (LW61xLPW2-1-6), suggesting dominance toward the high number of fruits/plant. The estimated values of heterosis over the better parent in these 8 crosses showed partial dominance for the large number of fruits in seven crosses, since they gave significant negative heterosis values. A complete dominance for the large number of fruits was detected in the remaining cross (LW61xLPW2-1-6) which showed insignificant positive value. Compared with the check hybrid, eleven crosses showed highly significant positive values of heterosis over the check hybrid ranging from 46.34\% (CLW1$1 \times L P W 12-3$ ) to $98.99 \%$ (CLW1-1xCLW4-2). It is suggested from the previous result that additive gene action was more important in the inheritance of this trait, since 13 crosses from 21 ones showed nodominance and seven crosses showed partial dominance (additive and non-additive).This suggestion was confirmed by analysis of variance due to GCA and SCA, which were highly significant, indicating the importance of both additive and non-additive gene actions, while the estimated ratio of $\sigma^{2} \mathrm{GCA} / \sigma^{2} \mathrm{SCA}$ which was 16.6, suggested that additive was more important in the inheritance of this trait. These results were agreed with those of Mankar et al. (1995), Prasath et al. (1998) and Singh et al. (2012) who showed heterosis in this trait. Also, similar results for the mode of gene actionwere obtained by Rai et al. (1998), Chezhian et al. (2000), Das and Barua (2001), Singh et al. (2002) and Patil et al. (2006).

As regard to average fruit weight, data in Table 8show that, the studied crosses exhibited no-dominance in 15ones, and dominance toward the small fruits was observed in sex ones, since they showed insignificant and significant negative values relative to mid-parents. Therefore, no heterosis over the better parent and check hybrid were detected, where all hybrids produced fruits significantly decreased in average fruit weight relative to better parent and check hybrid Snow F1. In this respect, absence of heterosis over better parent and check hybrid, did not imply the absence of superior F1 hybrids for total yield.

So, it could suggested that weight of eggplant fruits was mainly controlled by additive gene action. This suggestion was confirmed by the analysis of variance forcombining ability, since GCA and SCA mean squares were significant, indicating both additive 
and non-additive gene action were found in this trait, while the high ratio of $\sigma^{2} \mathrm{GCA} / \sigma^{2} \mathrm{SCA}(8.9)$, indicated that additive gene action play the main role in the inheritance of average fruit weight. These results are in agreement with those of Saraswathi (2003) and Ram and Singh (2012) who reported that all crosses exhibited significant negative heterosis for average fruit weight. Also, many researchers reported that additive gene action was more important than non-additive ones in the inheritance of this trait (Rai et al., 1998; Chezhian et al., 2001; Das and Barua, 2001; Ahmed et al., 2006; Suneetha and Kathiria, 2006; Ram and Singh, 2012).

Regarding fruit length and fruit diameter, data in Tables 9\&10 presented that, all studied crosses reflected no dominance for both traits, since they gave insignificant heterosis values over mid parent values. Therefore, no better parent heterosis or heterosis over the check hybrid were obtained. In this respect, we can suggest that fruit length and diameter were mainly governed by additive genetic variance. This suggestion was confirmed by estimated analysis of variance for combining ability, which revealed high significant and insignificant mean square values due to general and specific combining ability variances, respectively for both traits. Moreover, the estimated $\sigma^{2} \mathrm{GCA} / \sigma^{2} \mathrm{SCA}$ showed positive and negative values, respectively, indicated that only additive gene action play the significant role in the inheritance of fruit length and fruit diameter in eggplant crop. Similar results were obtained by Ram and Singh (2012) who reported that, none of the crosses (60 ones) exhibited heterosis for fruit diameter, also Saraswathi (2003) found the same trend for fruit diameter. Additive gene action was more important in the inheritance of both traits as reported by Ingal and Patil(1997); Das and Barua(2001); Suneetha and Kathiria (2006) and Ram and Singh (2012).

Generally, it is obvious from the determination of heterosis, dominance type and combining ability variances that, additive genetic variance played the main role in the inheritance of all studied characters, except total yield/plant.So, these characters could be improved by selection methods. While non-additive gene action was predominance and more important in the inheritance of total yield /plant, therefore hybrid breeding method is effective to improve total yield/plant.

Over two years of 2010 and 2012, there were four superior $F_{1}$ hybrids (LW6-1 x CLW4-2, LW14-1 x CLW4-2, CLW1-1 x CLW4-2 and CLW4-2 x LPW2-1$6)$ over the check hybrid "Snow" $F_{1}$ for total yield/plant. So, these crosses could be recommended to be used in commercial production of long eggplant.

Table (4): Average degree of heterosis (ADH\%) based on mid-parents (MP), better parent (BP), commercial hybrid $(\mathrm{CH})$, dominance type and combining ability variancesfor number of fruits / cluster in eggplant.

\begin{tabular}{|c|c|c|c|c|}
\hline \multirow{2}{*}{ Crosses } & \multicolumn{3}{|c|}{ ADH\% } & \multirow{2}{*}{ Dominance type } \\
\hline & MP & BP & $\mathbf{C H}$ & \\
\hline LW.6-1 x LW14-1 & 0 & & 0 & No-dominance \\
\hline LW.6-1 x CLW1-1 & $41.09 * *$ & $-14.34^{*}$ & $300 * *$ & Partial dominance \\
\hline LW6-1 x CLW4-2 & $69.51 * *$ & 10.21 & $267 * *$ & Complete dominance \\
\hline LW.6-1 x LPW2-1-6 & 0 & & 0 & No-dominance \\
\hline LW.6-1 x LPW12-3 & 0 & & 0 & No-dominance \\
\hline LW.6-1 x LB.78-4-1 & -0.37 & & 33 & No-dominance \\
\hline LW.14-1 x CLW.1-1 & $17.46^{*}$ & $-28.69 * *$ & $233^{* *}$ & Partial dominance \\
\hline LW.14-1 x CLW.4-2 & $53.81 * *$ & 0 & $233 * *$ & Complete dominance \\
\hline LW.14-1 x LPW.2-1-6 & 0 & & 0 & No-dominance \\
\hline LW.14-1 x LPW.12-3 & 0 & & 0 & No-dominance \\
\hline LW.14-1 x LB.78-4-1 & 25.09 & & $67 *$ & No-dominance \\
\hline CLW.1-1 x CLW.4-2 & 8.25 & & $333 * *$ & No-dominance \\
\hline CLW.1-1 x LPW.2-1-6 & 5.82 & & $200 * *$ & No-dominance \\
\hline CLW.1-1 x LPW.12-3 & -5.82 & & $167 * *$ & No-dominance \\
\hline CLW.1-1 x LB.78-4-1 & 5.05 & & $233 * *$ & No-dominance \\
\hline CLW.4-2 x LPW.2-1-6 & $23.33^{*}$ & $-19.82 * *$ & $167 * *$ & Partial dominance \\
\hline CLW.4-2 x LPW.12-3 & 7.62 & & $133 * *$ & No-dominance \\
\hline CLW.4-2 x LB.78-4-1 & -6.8 & & $133 * *$ & No-dominance \\
\hline LPW.2-1-6 x LPW.12-3 & 0 & & 0 & No-dominance \\
\hline LPW.2-1-6 x LB.78-4-1 & -0.37 & & 33 & No-dominance \\
\hline LPW.12-3 x LB.78-4-1 & -0.37 & & 33 & No-dominance \\
\hline \multicolumn{5}{|c|}{ Mean sum of square and variance ( MS $\left.\& \sigma^{2}\right)$} \\
\hline & & GCA & SCA & \\
\hline & Ms & $6.08^{* *}$ & $0.17 * *$ & \\
\hline & $\sigma^{2}$ & 0.82 & 0.11 & \\
\hline & $\mathrm{A} / \sigma^{2} \mathrm{SC}$ & & & \\
\hline
\end{tabular}


Table (5): Average degree of heterosis (ADH\%) based on mid-parents (MP), better parent (BP), commercial hybrid $(\mathrm{CH})$, dominance type and combining ability variances for percent of fruit clusters/plant in eggplant.

\begin{tabular}{|c|c|c|c|c|}
\hline \multirow{2}{*}{ Crosses } & \multicolumn{3}{|c|}{ ADH\% } & \multirow{2}{*}{ Dominance type } \\
\hline & MP & BP & $\mathbf{C H}$ & \\
\hline LW.6-1 x LW14-1 & 0 & & 0 & No-dominance \\
\hline LW.6-1 x CLW1-1 & $72.38 * *$ & $-12.67 * *$ & $6508 * *$ & Partial dominance \\
\hline LW6-1 x CLW4-2 & $84.73 * *$ & -6.11 & $5610 * *$ & Complete dominance \\
\hline LW.6-1 x LPW2-1-6 & 0 & & 0 & No-dominance \\
\hline LW.6-1 x LPW12-3 & 0 & & 0 & No-dominance \\
\hline LW.6-1 x LB.78-4-1 & 30.95 & & $1455^{* *}$ & No-dominance \\
\hline LW.14-1 x CLW.1-1 & $63.48 * *$ & $-17.18^{* *}$ & $6167 * *$ & Partial dominance \\
\hline LW.14-1 x CLW.4-2 & $89.03 * *$ & -3.93 & $5743 * *$ & Complete dominance \\
\hline LW.14-1 x LPW.2-1-6 & 0 & & 0 & No-dominance \\
\hline LW.14-1 x LPW.12-3 & 0 & & 0 & No-dominance \\
\hline LW.14-1 x LB.78-4-1 & 24.46 & & $1378 * *$ & No-dominance \\
\hline CLW.1-1 x CLW.4-2 & 4.59 & & $7038 * *$ & No-dominance \\
\hline CLW.1-1 x LPW.2-1-6 & $70.42 * *$ & $-13.66^{* *}$ & $6433 * *$ & Partial dominance \\
\hline CLW.1-1 x LPW.12-3 & $43.92 * *$ & $-27.09 * *$ & $5417 * *$ & Partial dominance \\
\hline CLW.1-1 x LB.78-4-1 & $26.76^{* *}$ & $-17.56^{* *}$ & $6138 * *$ & Partial dominance \\
\hline CLW.4-2 x LPW.2-1-6 & $53.51 * *$ & $-21.98 * *$ & $4645^{* *}$ & Partial dominance \\
\hline CLW.4-2 x LPW.12-3 & $24.94 * *$ & $-36.50 * *$ & $3762 * *$ & Partial dominance \\
\hline CLW.4-2 x LB.78-4-1 & $23.97 * *$ & $-14.83 * *$ & $5080 * *$ & Partial dominance \\
\hline LPW.2-1-6 x LPW.12-3 & 0 & & 0 & No-dominance \\
\hline LPW.2-1-6 x LB.78-4-1 & 13.09 & & $1243 * *$ & No-dominance \\
\hline LPW.12-3 x LB.78-4-1 & 5.52 & & $1153 * *$ & No-dominance \\
\hline \multicolumn{5}{|c|}{ Mean sum of square and variance ( MS \& $\sigma^{2}$ ) } \\
\hline & & GCA & SCA & \\
\hline & Ms & $3278.28 * *$ & $106.60 * *$ & \\
\hline & $\sigma^{2}$ & 363.63 & 100.99 & \\
\hline & $\mathrm{A} / \sigma^{2} \mathrm{SC}$ & & & \\
\hline
\end{tabular}

*,** Significant at 0.05 and 0.01 levels of probability, respectively .

Table (6): Average degree of heterosis (ADH\%) based on mid-parents (MP), better parent (BP), commercial hybrid $(\mathrm{CH})$, dominance type and combining ability variances for total yield/plant in eggplant.

\begin{tabular}{|c|c|c|c|c|}
\hline \multirow{2}{*}{ Crosses } & \multicolumn{3}{|c|}{ ADH $\%$} & \multirow{2}{*}{ Dominance type } \\
\hline & MP & BP & $\mathbf{C H}$ & \\
\hline LW.6-1 x LW14-1 & -1.64 & & $-27.55 * *$ & No-dominance \\
\hline LW.6-1 x CLW1-1 & $29.29 * *$ & $20.71 * *$ & -0.28 & Over dominance \\
\hline LW6-1 x CLW4-2 & $28.56 * *$ & $10.51 * *$ & $10.08 * *$ & Over dominance \\
\hline LW.6-1 x LPW2-1-6 & $9.71 *$ & $-3.47^{*}$ & $-8.98 * *$ & Partial dominance \\
\hline LW.6-1 x LPW12-3 & 1.15 & & $-24.36 * *$ & No-dominance \\
\hline LW.6-1 x LB.78-4-1 & $4.58 * *$ & $-6.58 * *$ & $-14.90 * *$ & Partial dominance \\
\hline LW.14-1 x CLW.1-1 & $28.02 * *$ & $22.64 * *$ & 1.31 & Over dominance \\
\hline LW.14-1 x CLW.4-2 & $24.29 * *$ & $9.35^{* *}$ & $8.93 * *$ & Over dominance \\
\hline LW.14-1 x LPW.2-1-6 & $3.78^{*}$ & $-6.47 * *$ & $-11.81 * *$ & Partial dominance \\
\hline LW.14-1 x LPW.12-3 & -1.99 & & $-24.75 * *$ & No-dominance \\
\hline LW.14-1 x LB.78-4-1 & 0.99 & & $-15.80 * *$ & No-dominance \\
\hline CLW.1-1 x CLW.4-2 & $13.31 * *$ & $3.64 *$ & $3.24 *$ & 0ver dominance \\
\hline CLW.1-1 x LPW.2-1-6 & $12.30 * *$ & $5.35^{* *}$ & -0.67 & Over dominance \\
\hline CLW.1-1 x LPW.12-3 & $18.80 * *$ & $15.42 * *$ & $-4.66 * *$ & Over dominance \\
\hline CLW.1-1 x LB.78-4-1 & $5.51 * *$ & 0.59 & $-8.36^{* *}$ & Complete dominance \\
\hline CLW.4-2 x LPW.2-1-6 & $7.71 * *$ & $4.83 * *$ & $4.43 * *$ & Over dominance \\
\hline CLW.4-2 x LPW.12-3 & $9.28 *$ & -2.63 & $-3.01 *$ & Complete dominance \\
\hline CLW.4-2 x LB.78-4-1 & $6.3^{* *}$ & 1.76 & 1.36 & Complete dominance \\
\hline LPW.2-1-6 x LPW.12-3 & 1.78 & & $-12.37 * *$ & No-dominance \\
\hline LPW.2-1-6 x LB.78-4-1 & -0.19 & & $-7.48 * *$ & No-dominance \\
\hline LPW.12-3 x LB.78-4-1 & 2.48 & & $-13.40 * *$ & No-dominance \\
\hline \multicolumn{5}{|c|}{ Mean sum of square and variance ( MS \& $\sigma^{2}$ ) } \\
\hline & & GCA & SCA & \\
\hline & Ms & $0.512 * *$ & $0.092 * *$ & \\
\hline & $\sigma^{2}$ & $0.057 * *$ & $0.089 * *$ & \\
\hline & $\mathrm{A} / \sigma^{2} \mathrm{SC}$ & & & \\
\hline
\end{tabular}

\footnotetext{
*** Significant at 0.05 and 0.01 levels of probability, respectively .
} 
Table (7): Average degree of heterosis (ADH\%) based on mid-parents (MP), better parent (BP), commercial hybrid $(\mathrm{CH})$, dominance type and combining ability variances for total fruit number/plant in eggplant.

\begin{tabular}{|c|c|c|c|c|}
\hline \multirow{2}{*}{ Crosses } & \multicolumn{3}{|c|}{ ADH\% } & \multirow{2}{*}{ Dominance type } \\
\hline & MP & BP & $\mathbf{C H}$ & \\
\hline LW.6-1 x LW14-1 & 6.98 & & -10.83 & No-dominance \\
\hline LW.6-1 x CLW1-1 & $13.06^{* *}$ & $-21.48 * *$ & $57.08 * *$ & Partial dominance \\
\hline LW6-1 x CLW4-2 & $8.82 * *$ & $-23.83 * *$ & $48.24 * *$ & Partial dominance \\
\hline LW.6-1 x LPW2-1-6 & $22.46^{* *}$ & 10.55 & 6.80 & Complete dominance \\
\hline LW.6-1 x LPW12-3 & -2.24 & & $-16.27 *$ & No-dominance \\
\hline LW.6-1 x LB.78-4-1 & 2.06 & & 0.78 & No-dominance \\
\hline LW.14-1 x CLW.1-1 & $14.24 * *$ & $-17.51 * *$ & $65.02 * *$ & Partial dominance \\
\hline LW.14-1 x CLW.4-2 & 7.90 & & $52.95 * *$ & No-dominance \\
\hline LW.14-1 x LPW.2-1-6 & 5.63 & & -2.04 & No-dominance \\
\hline LW.14-1 x LPW.12-3 & 0.94 & & -7.96 & No-dominance \\
\hline LW.14-1 x LB.78-4-1 & 0.49 & & 4.78 & No-dominance \\
\hline CLW.1-1 x CLW.4-2 & 0.84 & & $98.99 * *$ & No-dominance \\
\hline CLW.1-1 x LPW.2-1-6 & $15.92 * *$ & $-14.05 * *$ & $71.95 * *$ & Partial dominance \\
\hline CLW.1-1 x LPW.12-3 & -0.29 & & $46.34 * *$ & No-dominance \\
\hline CLW.1-1 x LB.78-4-1 & $12.29 * *$ & $-10.27 *$ & $79.50 * *$ & Partial dominance \\
\hline CLW.4-2 x LPW.2-1-6 & $13.28 * *$ & $-15.25 * *$ & $64.94 * *$ & Partial dominance \\
\hline CLW.4-2 x LPW.12-3 & $12.08^{* *}$ & $-17.05^{* *}$ & $61.44 * *$ & Partial dominance \\
\hline CLW.4-2 x LB.78-4-1 & 1.66 & & $59.76^{* *}$ & No-dominance \\
\hline LPW.2-1-6 x LPW.12-3 & 2.77 & & -2.32 & No-dominance \\
\hline LPW.2-1-6 x LB.78-4-1 & -0.74 & & 7.34 & No-dominance \\
\hline LPW.12-3 x LB.78-4-1 & -2.51 & & 3.90 & No-dominance \\
\hline \multicolumn{5}{|c|}{ Mean sum of square and variance ( MS $\left.\& \sigma^{2}\right)$} \\
\hline & & GCA & SCA & \\
\hline & Ms & $2754.40 * *$ & $31.10 * *$ & \\
\hline & $\sigma^{2}$ & $304.63^{* *}$ & $18.36^{* *}$ & \\
\hline & $\mathrm{AA} / \sigma^{2} \mathbf{S C}$ & & & \\
\hline
\end{tabular}

*,** Significant at 0.05 and 0.01 levels of probability, respectively .

Table (8): Average degree of heterosis (ADH\%) based on mid-parents (MP), better parent (BP), commercial hybrid $(\mathrm{CH})$, dominance type and combining ability variances for average fruit weight in eggplant.

\begin{tabular}{|c|c|c|c|c|}
\hline \multirow{2}{*}{ Crosses } & \multicolumn{3}{|c|}{ ADH $\%$} & \multirow{2}{*}{ Dominance type } \\
\hline & MP & BP & $\mathbf{C H}$ & \\
\hline LW.6-1 x LW14-1 & $-8.31 *$ & & $-18.92 * *$ & Dominance to low $\mathrm{P}$ \\
\hline LW.6-1 x CLW1-1 & -4.86 & & $-36.76 * *$ & No-dominance \\
\hline LW6-1 x CLW4-2 & 3.62 & & $-26.01 * *$ & No-dominance \\
\hline LW.6-1 x LPW2-1-6 & $-10.6^{*}$ & & $-15.23 * *$ & Dominance to low $\mathrm{P}$. \\
\hline LW.6-1 x LPW12-3 & 3.66 & & $-9.17 *$ & No-dominance \\
\hline LW.6-1 x LB.78-4-1 & 1.02 & & $-15.28 * *$ & No-dominance \\
\hline LW.14-1 x CLW.1-1 & -3.12 & & $-38.88 * *$ & No-dominance \\
\hline LW.14-1 x CLW.4-2 & 4.19 & & $-29.13 * *$ & No-dominance \\
\hline LW.14-1 x LPW.2-1-6 & -1.91 & & $-10.31 *$ & No-dominance \\
\hline LW.14-1 x LPW.12-3 & -3.13 & & $-18.40 * *$ & No-dominance \\
\hline LW.14-1 x LB.78-4-1 & 0.69 & & $-18.96 * *$ & No-dominance \\
\hline CLW.1-1 x CLW.4-2 & 11.99 & & $-48.42 * *$ & No-dominance \\
\hline CLW.1-1 x LPW.2-1-6 & $-17.16^{* *}$ & & $-42.44 * *$ & Dominance to low $\mathrm{P}$. \\
\hline CLW.1-1 x LPW.12-3 & 4.09 & & $-35.17 * *$ & No-dominance \\
\hline CLW.1-1 x LB.78-4-1 & $-13.15 * *$ & & $-49.17 * *$ & Dominance to low $\mathrm{P}$. \\
\hline CLW.4-2 x LPW.2-1-6 & $-15.15 * *$ & & $-36.86 * *$ & Dominance to low $\mathrm{P}$. \\
\hline CLW.4-2 x LPW.12-3 & $-11.04 * *$ & & $-40.21 * *$ & Dominance to low $\mathrm{P}$. \\
\hline CLW.4-2 x LB.78-4-1 & -0.25 & & $-36.70 * *$ & No-dominance \\
\hline LPW.2-1-6 x LPW.12-3 & -1.30 & & $-10.55^{*}$ & No-dominance \\
\hline LPW.2-1-6 x LB.78-4-1 & -1.05 & & $-14.03 * *$ & No-dominance \\
\hline LPW.12-3 x LB.78-4-1 & 4.38 & & $-16.84 * *$ & No-dominance \\
\hline \multicolumn{5}{|c|}{ Mean sum of square and variance ( $\left.\mathrm{MS} \& \sigma^{2}\right)$} \\
\hline & & GCA & SCA & \\
\hline & Ms & $354.82 * *$ & $8.36^{*}$ & \\
\hline & $\sigma^{2}$ & 38.98 & 4.35 & \\
\hline & $\overline{\mathrm{GCA}} / \sigma^{2} \mathrm{SC}$ & & & \\
\hline
\end{tabular}

\footnotetext{
*** Significant at 0.05 and 0.01 levels of probability, respectively .
} 
Table (9): Average degree of heterosis (ADH\%) based on mid-parents (MP), better parent (BP), commercial hybrid $(\mathrm{CH})$, dominance type and combining ability variances for fruit length in eggplant.

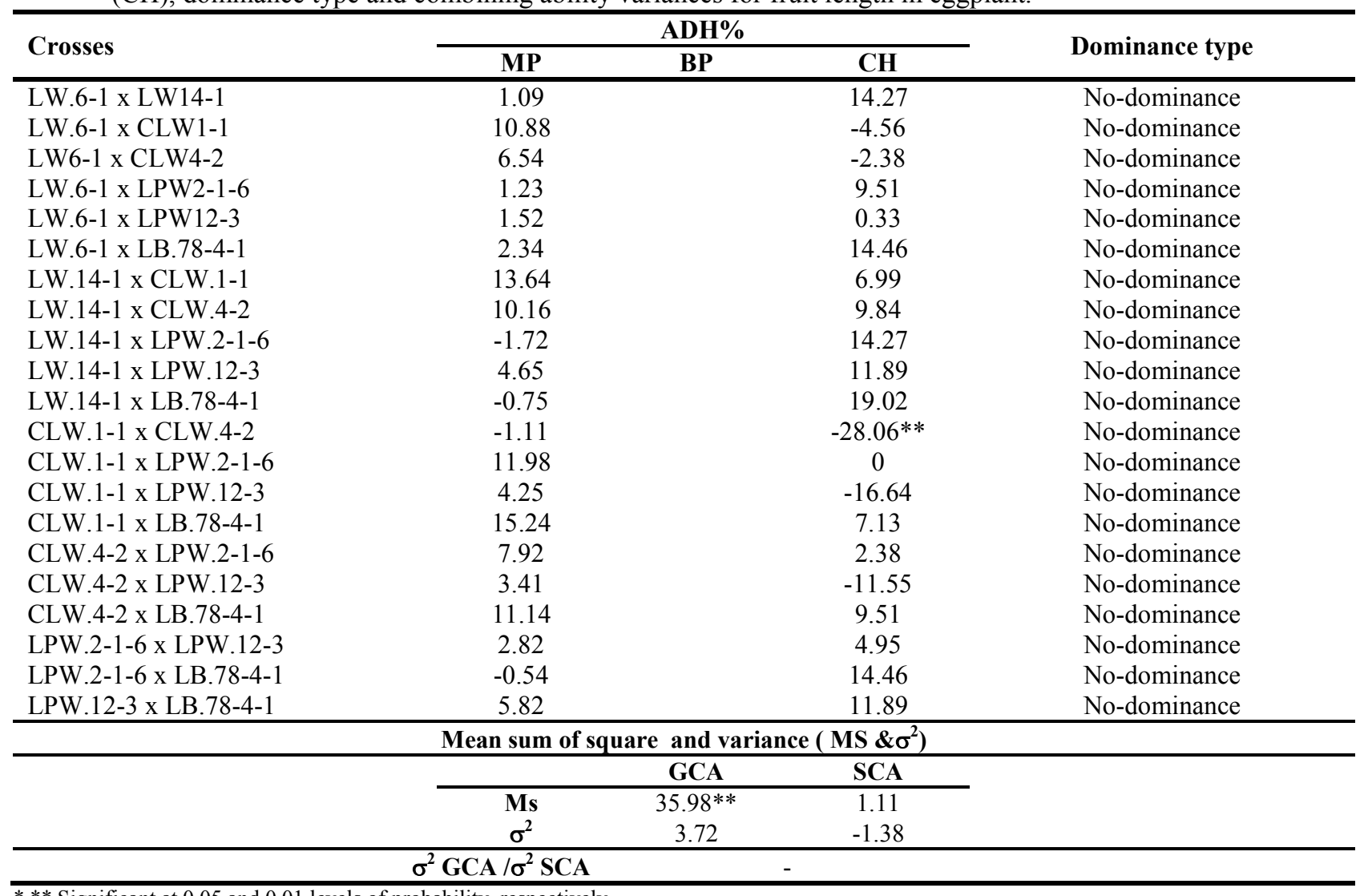

*** Significant at 0.05 and 0.01 levels of probability, respectively .

Table (10): Average degree of heterosis (ADH\%) based on mid-parents (MP), better parent (BP),commercial hybrid $(\mathrm{CH})$, dominance type and combining ability variances for fruit diameter in eggplant.

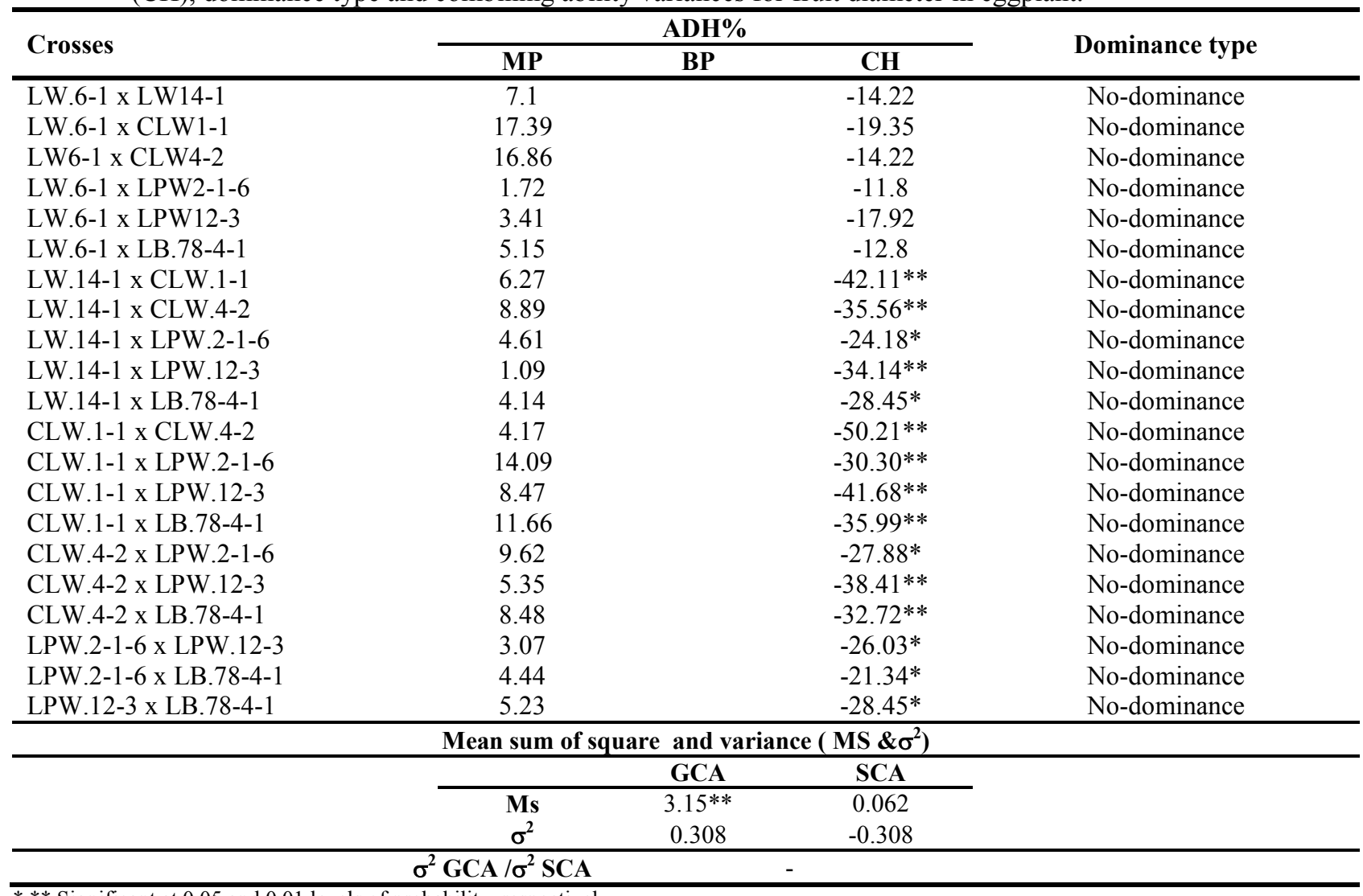

*** Significant at 0.05 and 0.01 levels of probability, respectively . 


\section{REFERENCES}

Ahmed, N.; M. Mehdi; J. Nayeema and A.K. Singh (2006). Inheritance of quantitative characters in eggplant (Solanum melongena L.). Indian J. Hort. 63(2): 218-220.

Aswani, R.C. and R.C. Khandelwal (2005). Combining ability in brinjal. Indian J. Hort. 62(1): 37-40.

Bendale, V.W.; S.V. Mane; S.G. Bhave; R.R. Madav and S.B. Desai (2005). Combining ability studies on growth and development character in brinjal (Solanum melongena L.). International J. Agric. Sci. 1(1): 30-33. (C.F.CAB Abst. AN: 20063106423)

Chezhian, P.; S. Babu and J. Ganesan (2000). Combining ability studies in eggplant (Solanum melongena L.). Tropical Agric. Res. 12: 394-397.

Cochran, W.G. and G.M. Cox (1957). Experimental Designs.2nd ed., John Willey and Sons, New York,USA. $611 \mathrm{p}$.

Das, G. and N.S. Barua (2001). Heterosis and combining ability for yield and its components in brinjal. Annals Agric. Res. 22(3): 399-403.

Griffing, B. (1956). Concept of general and specific combining ability in relation to diallel crossing system. Aust. J. Biol. Sci., 9: 463-493.

Ingale, B.V. and S.J. Patil (1996). Heterosis for fruit characteristics in egg palnt. J. Maharashtra Agric. Uni. 21(3): 390-393. (C.F.CAB Abst., IS: 19960378-2395)

Ingale, B.V. and S.J. Patil (1997). Diallel analysis for fruit characteristics in eggplant. PKV. Res. J. 21(1): 30-34. (C.F.CAB Abst., IS: 19970378$813 \mathrm{x})$.

Jain, S.K. and E.V.D. Sastry (2012). Heterosis and combining ability for grain yield and its contributing traits in bread wheat (Triticuma estivumL.). Res. \& Reviews 1:17-22.

Kansouh, A.M. (2014). Association of hybrid performance, heterosis and dominance types in pepper (Capsicum annuum L.). J. of Plant Production, Mansoura Univ., Vol.5 (8):1471-1490.

Kansouh, A.M. and A.H. Hussein (2009). Developing new lines of eggplant (Solanum melongena L.) by selection. Egypt. J. Appl. Sci. 24(12b):650-665.

Kaur, J.; J.A. Patel; M.J. Patel; A.S. Bhanvadi and R.R. Acharya (2001). Heterosis for fruit yield and its components in brinjal (Solanum melongena L.). Capsicum and Eggplant Newsletter 20: 102-105.

Kavita, A.; I.B. Maurya and S.S. Lakhawat (2005). Inheritance of yield in brinjal.Udyanika J. Hort. Sci. 11(2): 87-89. (C.F. CAB Abst., 2009, AN: 20093087566).

Kumar, S.R.; T. Arumugam and V. Permalakshmi (2012). Evaluation and variability studies in local types of brinjalfor yield and quality (Solanum melongena L.). Elec. J. Plant Breed. 3(4): 977-982.

Mandal, N. and I. Dana (1993). Heritability and heterosis study in brinjal(Solanum melongena L.). Environ. and Ecology 11(2) 295-298.

Mankar, S.W.; P.B. Kale; V.N. Dod; R.V. Wankhade and B.J. Jadhao (1995). Heterosis in eggplant
(Solanum melongena L.). Crop Res. Hisar 10(3): 331-337.

Patil, S.D.; S.A. Ranpise and T.A. More (2006). Combining ability studies for growth and yield characters in eggplant (Solanum melongena L.). Advances in Plant Sciences 19(2): 627-631.

Praneetha, S.; T. Sarasvathy; D. Veeraragrvathatham and L. Pugalendhi (2013). Per se performance and heterosis for shoot and fruit borer (Leucinode sorbonalis $\mathrm{Gn}$ ) resistance and yield in brinjal (Solanummelongena L.). Elec. J. Plan. Breed. 4(1): 1061-1066. (C.F. CAB Abst., AN: 20133138369).

Prasath, D.; S. Natarajan and S. Thamburaj (1998). Studies on heterosis in eggplant (Solanum melongena L.). South Indian Hort., 46(3-6): $247-$ 250.

Rai, N.; A.K. Singh; Vijay Kumar and V. Kumar (1998). Improvement in long shape brinjal hybrids. Orissa J. Hort. 26(2): 42-46.

Ram, K. and P. Singh (2012). Heterosis and inbreeding depression in relation to other genetic parameters in eggplant.Asian J. Bio. Sci., 7(2): 163-168.

Ramireddy, S.R.K.M.; H.B. Lingaiah; P. Naresh; P.V.K. Reddy and V.S. Kuchi (2011). Heterosis studies for yield and yield attributing characters in brinjal (Solanum melongena L.). Plant Archieves 11(2): 649-653.

Rotino, G.L.; N. Acciarri; G. Tamietti; E. Sabatini; S. Voltattorni; D. Valentino; P. Alberti; M.G. Tacconi; G. Gvazioli; R. Pedrstti; F. Cavallanti and L. Toppino (2007). Development of eggplant cluster mini fruit types and valorization of Italian landraces. ItalusHortus. 14(2): 41-48.

Sao, A. and N. Mehta (2010). Heterosis in relation to combining ability for yield and quality attributes in brinjal (Solanum melongena L.). Elec.J. Plan. Breed., 1(4): 783-788

Saraswathi, T. (2003). Studies on residual heterosis in the segregation population of brinjal. South Indian Hor. 51(1/6):149-151.

Shafeeq, A.; K. Mashusudan; R.R. Hanchinal; A.G. Vijaya Kumar and P.M. Salimath (2007). Heterosis in brinjal. Karnataka J. Agr. Sci., 20(1): 33-40. (C.F. CAB Abst., AN: 20083091050).

Singh, H.V.; S.P. Singh; Major Singh; Stayendra Singh; M. Singh and S. Singh (2002). Genetic analysis of quantitative traits in brinjal. Vet.Sci. 29(1): 84-86.

Singh, K.; A.S. Sidhu and A. Kumar (2012). Heterosis for yield and its components in brinjal (Solanum melongena L.). J. Hort. Sci. 7(2): 142-144.

Snedecor,G.W. and W.G.Cochran, (1990). Statistical Methods $7^{\text {th }}$ ed.. Iowa State Univ. Press. Ames. Iowa, USA.593 p.

Suneetha, Y. and K.B. Kathiria (2006). Studies on combining ability in round brinjal (Solanum melongena L.). International J. Plant Sci. Muzaffarnagar, 1(1): 48-51. (C.F. CAB Abst., AN: 20073098817).

Valavigna, A. (2007). Proceeding of the National Research Project "Valorization of Italian vegetable local varieties". Bologna, Italy, 8 September 2005. (C.F. CAB Abst., 2005-2009, AN: 20083094051). 


\section{قوة الهجين وعلاقتها بتباين القدرة على التآلف في الباذنجان \\ محمود إبراهيم محمود لئي}

قسم الإنتاج النباتي (خضر) - كليه العلوم الزراعية البيئية بالعريش- جامعه قناة السويس - مصر

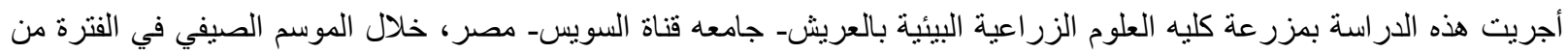

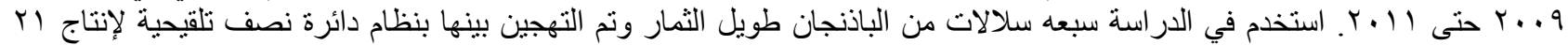

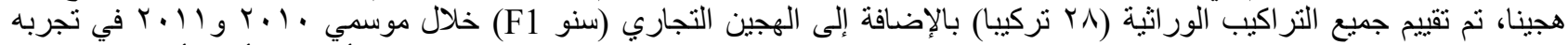

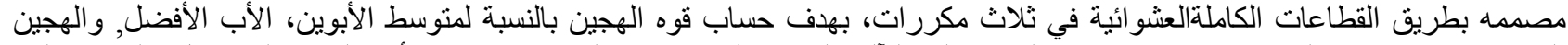

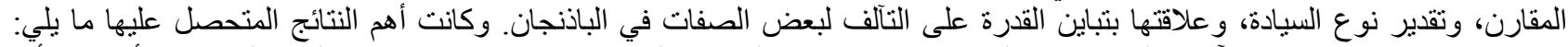

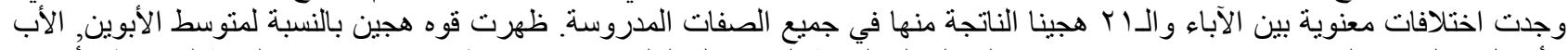

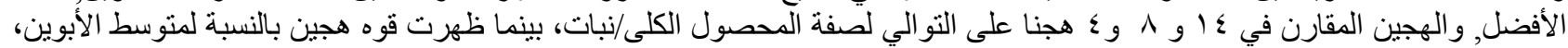

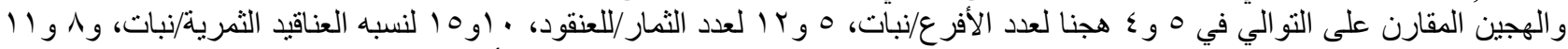

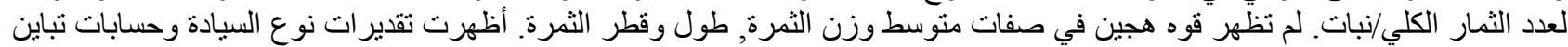

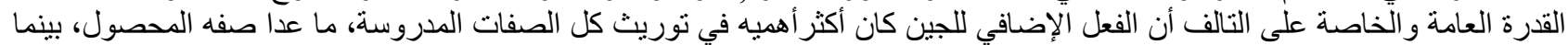

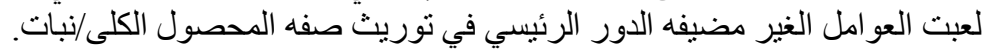

